except the unification of powers, and in that respect it improves radically upon the existing three-headed government. It creates a commission and manager who work together in the usual way subject to the additional requirement that the commission must annually and in person submit its major projects to a large popular body and secure from it money and consent before going ahead.

You accept the idea as rather good, subject to the reserved privilege of changing your mind as often as you please?

So do I!

\title{
REFLECTIONS ABOUT STATE LEGISLATURES
}

\author{
BY H. S. GII_BERTSON ${ }^{1}$
}

New York City

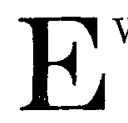

VERY second winter in forty states, a common resolve is forming itself in the minds of countless discontented and forward-looking and designing people. The big building with a gilded dome in the capital city becomes the mecca of two great companies of those who long to make things better, and of those who are just as keenly interested in keeping them just as they are. For ours is a "government of laws"; the world is to be set right and kept right by enactment, and people flock to the legislature to "get a law passed."

The legislature by common consent is such an all-around, all-sufficient instrument of human welfare that democracies everywhere but in America have made it the very keystone of their systems of government. To the legislature they have been careful to make every other political agency definitely subordinate. They have considered that the control of the laws is the control of all.

Here in America, by contrast, the legislature has been allowed to fall into obscurity, to become so badly manned and equipped, and so unwieldy and uncertain in its responses that it is everywhere but a poor weapon in the hands of a people who call themselves free. We have taken some action to fit it to better uses, it is true. We have trimmed away its powers, by limiting the subjects which it may treat, by establishing minute rules for its procedure, by shortening its sessions. But, notwithstanding, the quantity of laws has steadily increased and their quality generally deteriorated. And as for its personnel, in some of the states, it has reached the very depths. In at least one state ${ }^{2}$ the ordinary process of lawmaking has ceased to be seriously regarded as a means to progressive ends.

${ }^{1}$ Executive secretary, National Short Ballot Organization.

${ }^{2}$ Oregon. 


\section{LEGISLATIVE DEGENERATION}

It must be frankly admitted that the story of American state legislatures is a record of degeneration. The worst enemies of the people could have executed no more effective coup d'etat in behalf of oligarchy than did their best friends when they set up the machinery for throwing the legislature into the background. They simply put innumerable minor officers on the ballot in the name of a more complete democracy. A coroner, a sheriff, a secretary of state and anywhere between a dozen and fifty others, the mere errand boys of the law, became not equal but superior to the direct representatives of the people. The candidates for what, logically, is the one office of highest importance in a republic, were henceforth on election day to be lost in the woods and the voters were to loosen their grip on their most powerful leverage to power.

By the same sign the obscurity of the legislature was intensified by lessening the political importance of the individual member. The New Hampshire house of representatives has a membership of four hundred. Each member is but one four-hundredth part of a great mass meeting. In New York each assemblyman represents one one-hundred and fiftieth of the people. But even the one hundred and fifty are but one of three distinct branches of the law-making power. Small men for small jobs!that is what the public has come to think of legislative office-a state of mind that grows out of the intricate ballot and minute divisions of authority. The wonder is that legislatures contain as many men of weight as they do.

But the confusion and obscurity only begin at the ballot.

\section{THE EFFECT OF SPOILS}

When the session opens it is in an atmosphere, thick with extraneous issues, that of necessity dims the vision of the members to the greater interests of their constituents. The great and glorious company of door-keepers, sergeants-at-arms, clerks and messengers that swarm the legislative halls in the larger states, represent bargainings of principle for votes and of independence for practical results, just so many links that tie the individual members to the common fortunes of combinations which no one for a moment believes are working in behalf of the general good. A mechanical obstacle has been set up to single-hearted, public-spirited action by the spoils which prevail in every state legislature except that of Wisconsin, where the merit system is in operation.

In the upper house of most of the states the patronage evil takes another form through the power of confirmation of the governor's appointments. Originally intended as an instrument for eliminating the unft, this bridge between the executive and legislative branches has become the basis of a system of partisan barter and intrigue and a shield 
for the governor from public criticism of unfit appointments, and an obstruction to clear thinking and single allegiance.

Of the same genus is that great mass of special legislation that has grown up in many states to meet the needs of cities and counties. It has taken the legislators far afield from the main purposes of their office; it has impaired local self-government. But above all it has created endless opportunity for back-scratching and log-rolling, for casting shadows on the really important concerns of the people of the whole state whose servant the legislature is.

But the irresponsibility and obscurity of the state legislature are by no means "acquired characteristics"; they were not altogether achieved in the course of its development.

The fact is, American legislatures as we know them today took shape amid the influences of the Revolutionary period when monarchy was making an especially wicked exhibition of itself and yet before democracy had become a widely accepted principle. Democracy took a forward step in the early colonial period when the second or lower house became an institution. "The people" thereby acquired an instrument of negative control; they were grateful for small favors.

\section{THE UPPER CHAMBER}

In the federal constitutional convention the upper chamber idea received the approbation of conspicuous conservatives and reactionaries. But the tide by this time had turned. Now it was the propertied classes that sought to hold down the people at large. Alexander Hamilton even went so far as to suggest that senators, like judges, should hold office during good behavior. During the best days of the slave power it found one of its stoutest champions in the person of John C. Calhoun. That the designs of its champions were realized is attested by Woodrow Wilson when he summed up the case by saying that the senate is valuable in our democracy in proportion as it is undemocratic.

With the passing of the Adams and Hamiltonian group and the accession of the New West as a factor in national politics, democracy and equality became, formally at least, the order of the day. Men began to talk less freely and openly of "classes." The defense of the second chamber from the time of de Tocqueville shifted its grounds to considerations of the deliberative quality of the second chambers-on which point of view a typical expression is that of Prof. John W. Burgess:

The primary purpose of the legislature is to ascertain what the law ought to be, to determine not what the will of the people commands, but what the reason of the people, the common commissioners demands. . . A legislature of one chamber inclines too much to radicalism. One of three chambers or more would incline too much to conservatism. The true mean between conservatism and progress, and therefore the true interpretation of the common commissioners at 
each particular moment, will be best secured by a legislature of two chambers.

The thinking of the country set more and more strongly toward a more perfect rule of the people. By a curious perversion of fate the machinery of self-government adapted itself more and more perfectly to the needs of the few. Legislative organization contributed its full share to the growth of invisible government. The demand for "more democracy" as a cure for partial democracy took shape in bigger legislative assemblies. This diminished the calibre of the individual members. Beyond that, it intensified the mob character of the assemblies-and mobs require dictators. This factor, together with the growing volume of business to be dispatched, brought about the need of a compact inner organization. The power of the speaker grew apace. Through his authority to recognize or not to recognize and to refer measures to friendly or unfriendly committees he came to hold the fate of pending legislation in the hollow of his hand. The individual member was reduced to the status of a trading unit.

\section{THE COMMITTEE SYSTEM}

People became so disgusted with the output of such methods that they resorted to another drastic remedy: they shortened the sessions to cut off the flow of laws. But this remedy like most of those which it preceded and followed, only aggravated the trouble. It was a simple matter of arithmetic. Given, let us say, a thousand measures to be considered; given also a sixty-day period in every two years in which to do it. It is obvious that a good many measures had to be kept going through the mill at the same time. To meet this situation the committee system became more and more indispensable. With this, open deliberation largely ceased and each committee became a little legislature by itself, obscure and irresponsible.

And so, seemingly, every device that could be invented to minimize the importance of the legislature and its individual members in the eyes of the voters, to distract the attention of the legislator from the proper business in hand, to center power in the hands of the few, but without responsibility or publicity, has been put to the test in the making of this all important engine of self-government. What was intended to insure deliberation has become an all too available instrument of evasion. For it has been the practice of one house confronted by a popular, but inconvenient measure, to pass it, in the hope and belief that the lapse of time will prevent its consideration in the other house and that it will thereupon die by limitation. Meanwhile the party of the first part gets the credit for being exceedingly responsive to the people's wishes; while the second is just simply too crowded with business to take action on the measure in question. 
As the government not known to the constitution has desired action or inaction, haste or deliberation, so have the legislatures moved. No mere element of official organization has been able either to accelerate or retard. Only by some supreme effort or some accidental combination of circumstances at comparatively infrequent intervals have the great body of the people found themselves in power.

\section{PRINCIPLES UNDERLYING REORGANIZATION}

What to do about it, that is the question.

The new political science, replacing the doctrine of repression and negation and putting it squarely up to the people to make democracy real, says: "Make government visible, turn the light on the ballot, smoke out the public servants into the open, fix responsibility all along the line, concentrate the whole political force of the whole people on each successive issue. If the system breaks down, then it is time to call in the Kaiser."

Better law-making, then, is not a matter of a single, simple step. It calls for a straightening out of the battle line along the whole front.

\section{NEEDED SIMPLIFICATIONS}

Begin by taking off the back of the legislature, responsibilities which properly fall upon other shoulders-relieve Albany, Springfield, Boston, of their concern over innumerable measures-that run up into the hundreds at every session-which should be the "worry" of particular cities and counties. Clear the legislator of the temptation to trade the interests of his constituents against the welfare of the whole state and you have already done much to establish that singleness of sight which is the highest virtue of a law maker. Twelve states have already accepted this principle of municipal home rule and the body of laws in those states is the healthier for it.

Simplification No. 2 would consist of relieving the legislature of its non-legislative duties. The swarms of legislative employes that throng some of the state capitols on pay day would cease to be a distracting influence to the members with political debts to pay, if every one of them were appointed, as they are in Wisconsin, under the rules of the civil service commission. There is perhaps as great or greater reason why the merit system should prevail in legislative bodies where fundamentals of government are dealt with, than in the administrative branch.

Simplification No. 3 would concern itself with stripping the mind of the voter and the citizen of confusing issues on election day and helping him to concentrate his power where it ought to count most. This is the principle of the short ballot. If the people are to think clearly, see straight and act single-mindedly, when they are giving their sailing orders, it is obvious that a deal of cutting away of rubbish will have to be 
undertaken at that all-important point. From the standpoint of effective voting, such officers as coroners, sheriffs, secretaries of state, attorneysgeneral and their like, are plain trash. The candidates for the legislature must be made infinitely more prominent and conspicuous than clerks of courts. The attention of the electorate must be diverted from non-essentials and false issues-the mere cogs of the governmental machine,- to the legislating or policy determining officers, who need all the room on the ballot.

(By a happy coincidence, the same pruning away of the ballot which would throw the legislature into high relief also works out in the interest of a better organized, better controlled executive department; but that is a story by itself.)

Then finally the internal simplification of the legislature itself. It is vital that the people should know where their law makers "live." No more of the moving platform or the three ring circus. No more vibration of responsibility from the senate to the assembly and back again, to the reward of the dodger and the "pussy-footer." No more privileged machinery of obstruction. When once the whole people's mind is really made up, every consideration of democracy dictates that it should prevail. The remedy is the unicameral system: one house and a comparatively small one-big enough to represent everybody but small enough to be watched and to talk things out.

\section{ONE HOUSE AND A SMALL ONE}

The idea is not new. Governor Hodges stirred the country four years ago with an appeal to the legislature of Kansas for the establishment of the plan in that state. The success of commission government, the abandonment of the clumsy two-chambered city councils in many of the larger cities, have blazed the way for the extension of the idea to states. It is supported by the weight of authority in political science and practical statesmanship as represented by such men as John Stuart Mill and Benjamin Franklin. Switzerland, Norway and most of the Canadian provinces have the unicameral system and have found it good.

But how construct a single house? No careful system applicable to our peculiar conditions appears as yet to have been worked out. Such a body will be constituted in different ways according to the peculiar massing of the people in cities and in rural districts and on different lines of communication and to their distribution in industries and occupations and along lines of nationality. Whether the selection of representatives shall be made by geographical divisions or according to some other classification is a separate question to be worked out by the case method, in each jurisdiction. The main point is that the legislative body shall be representative in the fullest sense.

It then becomes necessary to decide what, after all, is the represen- 
tative's actual function. Here we shall surely be compelled to base our calculations on human nature as we find it and not as we think it ought to be. The English people, who have the longest experience with selfgovernment, have evolved, probably instinctively, a plan for the functioning of the people through election machinery which seems to give them the very maximum of political power. What can the crowd which we call an electorate effectively do? Only by a miracle could a whole constituency have at the same moment precisely the same deliberate thought on the same subject. It is true that crowds have common impulses, but who would base legislation upon impulse?. What then does lead the crowd to have a common thought and conviction? Undoubtedly it comes about that someone has a theory of action; he puts it into form; possibly he makes clear and sharp the vague mental gropings of a number of men. Through explanation, discussion, agitation and organization it becomes the common property of a growing constituency, perhaps of a majority. And so the crowd puts its seal of approval on the proposal. It assents or dissents but, as a crowd, it does not initiate.

THE LEGISLATIVE LEADER

Now that is a cardinal fact to be recognized in the construction of legislative bodies: the ultimate and all important duty and function of the people and even of their representative bodies must be simply to assent and dissent. To a single leader or group of leaders must fall the responsibility of initiative; of interpreting, crystallizing and formulating the vague and dormant thoughts of the people and submitting their formulations to them for correction and adjustment.

We must set up in our legislative bodies the definite machinery of initiative and assent. If we fail to do so the actual management of legislation will continue to lie outside the control of the people, in the hands of unofficial and irresponsible leaders. For leaders there must be.

In the further interest of presenting to the people a clear unobstructed view of doings at the state house; the major legislative issues must be brought up for treatment, not in a heterogeneous muddle but one at a time, or as nearly so as the volume of necessary legislation will permit. This cannot be the case if we cling to the tradition of the sixty-day or ninety-day biennial session which is in vogue in most of the states. For the short session means congestion, which can only be relieved by dividing the legislature into numerous little legislatures.

It becomes necessary, then, to accept the principle of the continuous session. "Let that bunch at the capitol stay in session all the year round!' will be the first and most natural reaction of the man on the street to this proposal. The answer will be "No, not that bunch, but a very differently constituted bunch, visible, responsible and armed with the tools for expert action. And not in continual session for the passage 
of measures, but what is of equal or even greater importance, for preparation of and for preliminary deliberation upon pending legislation, one measure at a time- which is a very different proposition."

To come now to the definite form of such a legislative organization. Take for simplicity's sake a state of fairly homogeneous population like Iowa, Kansas, Nebraska, or one of the Dakotas. How shall we incorporate the principles of leadership and assent, provide for deliberation and continuous session?

The suggested procedure might be somewhat as follows: To begin with, it seems reasonable to suppose the needs of representation would be simply met in a single legislative chamber of perhaps fifty members. How shall they be chosen? Obviously no voter would care to send fifty delegates to the state house. He simply would not select that number or anything like it. The actual selections under some disguise or other would have to be made for him by some unofficial body. A system of proportional representation could easily be devised to fit the situation, or if this principle should seem to be too much of a novelty, the logical plan would be to divide the state into districts of approximately equal population. The districts, however, should be few in number with a view to investing the individual representative with a greater importance and thereby increasing his visibility.

Concretely, let us propose ten districts in each of which there would be selected on a general ticket, five representatives. From their own number each of the ten groups of five would choose one member as their official leader, with some such distinctive title as "legislative councillor."

\section{LEGISLATIVE COUNCILLORS}

The "legislative councillors" from the ten districts would constitute that inevitable group in the legislative assembly which must take the initiative in all matters. But this, unlike the coteries which control the legislatures now, would be an official body and would constitute the chosen leadership of every section of the state, the positive force in lawmaking.

The legislative council, and not the entire membership, would sit between sessions, continuously, if necessary, in the capacity of a committee, in lieu of many committees sitting simultaneously. It would hold hearings, receive bills for introduction, supervise the drafting of laws and furnish a permanent connecting link between the people and the administrative or operating branch of the government.

The legislature proper would meet annually, principally only for the purpose of final debate and passage of measures. Its action would of course not be dependent upon the will of the legislative council, for it would have the power to receive measures on its own account and refer them to its own committees. The governor himself should either have a 
seat in the body or it should have access to him and he to it, at all times.

Some such arrangement as this would tend to make the legislature a simple, dignified, orderly, understandable body upon whom would be focussed a strong light of publicity. It could not escape accountability to the people. Armed with an expert staff of investigators and bill drafters it would be without excuse for hasty or ill-considered action. The autocracy of the speaker would give way. The needs of progressive democracy for the machinery of positive expression in the statutes would thus be met.

\title{
AMERICAN CITIES AS FOSTER-MOTHERS
}

\author{
BY MRS. N. M. FORBES ${ }^{1}$ \\ London, England
}

\section{$\mathrm{A}$}

FTER the war, what? In our war hospital work in France the immediate needs are so pressing that only in flashes is there opportunity to see beyond the horrors of today. In these flashes we nurses realize that ours is not all the work. We are helping to save the lives of those who are fighting to save France and liberty. After us must come those who will help restore the ruined France in order that the regained liberty may be enjoyed. One lonely rainy night I started building a castle in Spain and I saw the blackened fields again green, the blue smoke once more curling up from cottages and towns and the laughter of children once more heard.

Cannot this castle in Spain, like many another, become a reality?

\section{THE TASK OF REBUILDING}

All through the invaded district, and especially along the battle lines in France and Belgium, cities, towns, villages and farms have been devastated. Family and community life have been destroyed, the means of support have been cut off, and next to nothing remains of the schools, churches and other things that tend toward a higher life.

To rebuild these cities, towns, villages and farms, and reunite and re-establish families and communities, give them a means of earning a livelihood, and furnish them with schools, universities, libraries, museums, hospitals, churches and cathedrals-is a task of reconstruction perhaps as great and as important as that of supporting the army that must check the inroads of militarism and preserve the world for liberty.

The French have taken hold of the military task cheerfully and unflinchingly. They have been doing the same with the task of caring for the people from the devastated and occupied regions. They have shown

\footnotetext{
${ }^{1} \mathrm{Mrs}$. Forbes has since the outbreak of the war been serving in France as a French Red Cross nurse.
} 